\title{
Preliminary Feasibility Study of a Hybrid Solar and Modular Pumped Storage Hydro System at Biosphere 2
}

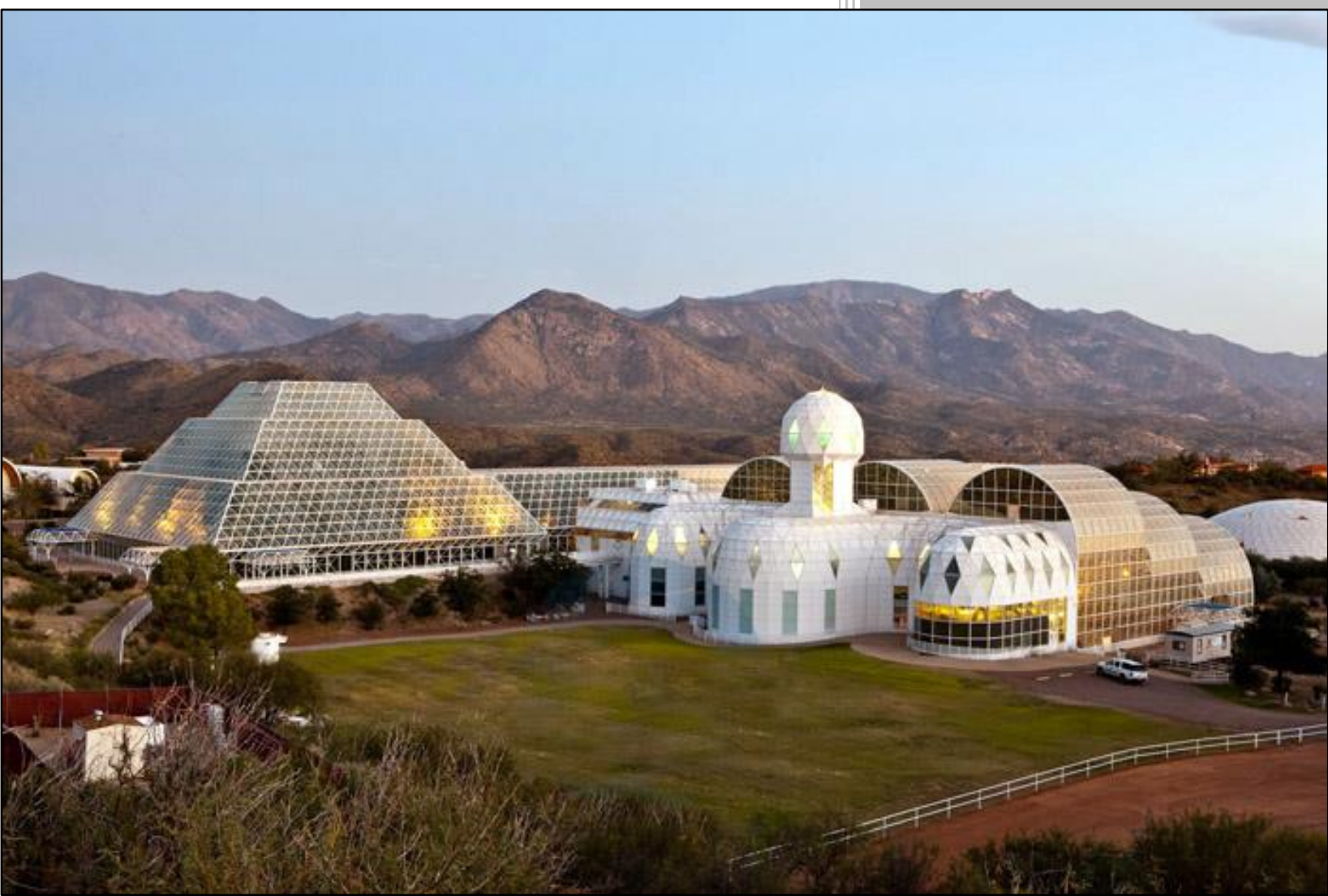

Approved for public release. Distribution is unlimited.
Adam Witt

Rebecca Brink Dol Raj Chalise Boualem Hadjerioua Kevin Lansey Chris Hortsman

September 2016 


\title{
DOCUMENT AVAILABILITY
}

Reports produced after January 1, 1996, are generally available free via US Department of Energy (DOE) SciTech Connect.

Website http://www.osti.gov/scitech/

Reports produced before January 1, 1996, may be purchased by members of the public from the following source:

\author{
National Technical Information Service \\ 5285 Port Royal Road \\ Springfield, VA 22161 \\ Telephone 703-605-6000 (1-800-553-6847) \\ TDD 703-487-4639 \\ Fax 703-605-6900 \\ E-mail info@ntis.gov \\ Website http://www.ntis.gov/help/ordermethods.aspx
}

Reports are available to DOE employees, DOE contractors, Energy Technology Data Exchange representatives, and International Nuclear Information System representatives from the following source:

Office of Scientific and Technical Information

PO Box 62

Oak Ridge, TN 37831

Telephone 865-576-8401

Fax 865-576-5728

E-mail reports@osti.gov

Website http://www.osti.gov/contact.html

This report was prepared as an account of work sponsored by an agency of the United States Government. Neither the United States Government nor any agency thereof, nor any of their employees, makes any warranty, express or implied, or assumes any legal liability or responsibility for the accuracy, completeness, or usefulness of any information, apparatus, product, or process disclosed, or represents that its use would not infringe privately owned rights. Reference herein to any specific commercial product, process, or service by trade name, trademark, manufacturer, or otherwise, does not necessarily constitute or imply its endorsement, recommendation, or favoring by the United States Government or any agency thereof. The views and opinions of authors expressed herein do not necessarily state or reflect those of the United States Government or any agency thereof. 
Environmental Sciences Division

Feasibility Study of a Hybrid Solar and Modular Pumped Storage Hydro System

Adam Witt, Oak Ridge National Laboratory

Rebecca Brink, New Mexico Institute of Mining and Technology

Dol Raj Chalise, Oak Ridge National Laboratory Boualem Hadjerioua, Oak Ridge National Laboratory

Kevin Lansey, University of Arizona

Chris Hortsman, University of Arizona

Date Published: September 2016

\author{
Prepared by \\ OAK RIDGE NATIONAL LABORATORY \\ Oak Ridge, TN 37831-6283 \\ managed by \\ UT-BATTELLE, LLC \\ for the \\ US DEPARTMENT OF ENERGY \\ Contract DE-AC05-00OR22725
}





\section{CONTENTS}

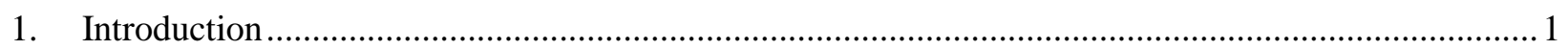

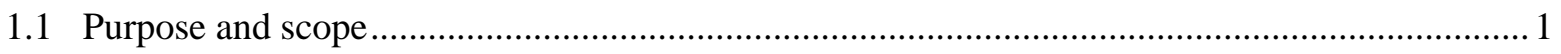

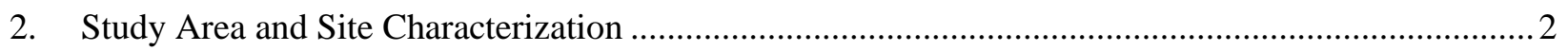

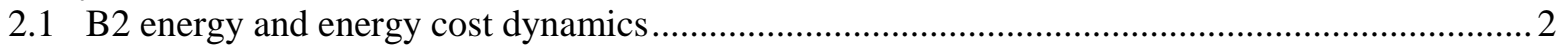

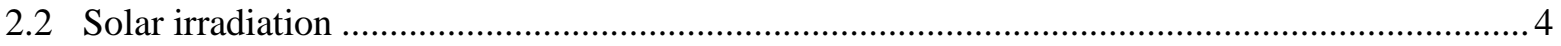

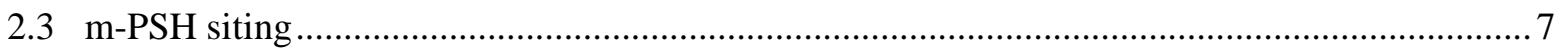

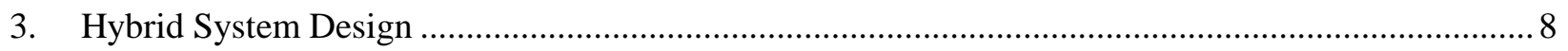

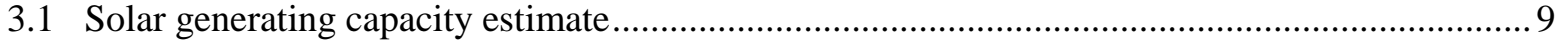

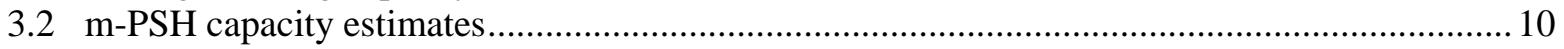

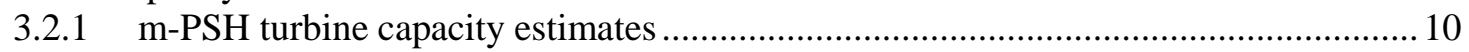

3.2.2 m-PSH water storage tank capacity estimates ................................................. 11

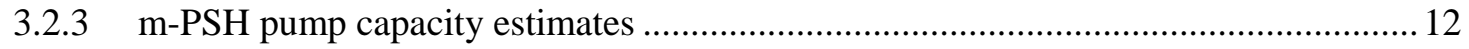

3.2.4 m-PSH water conveyance capacity estimates......................................................... 13

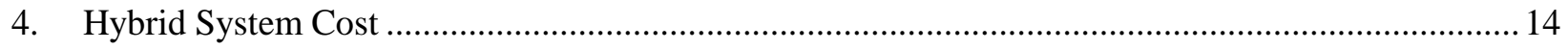

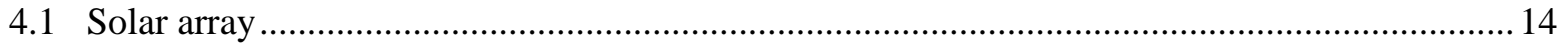

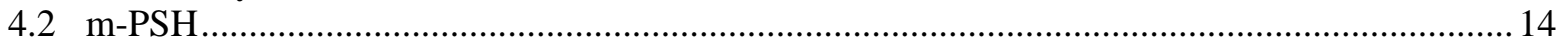

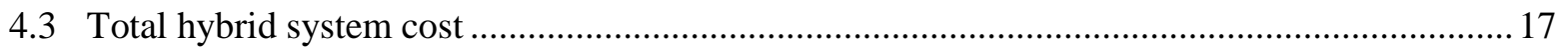

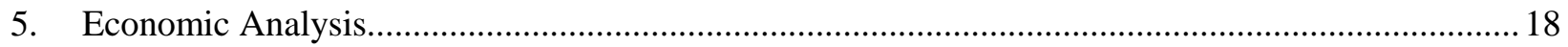

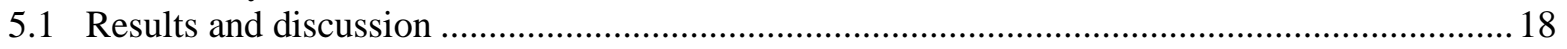

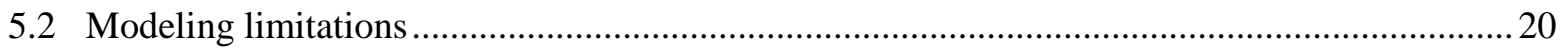

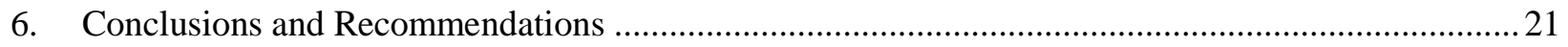

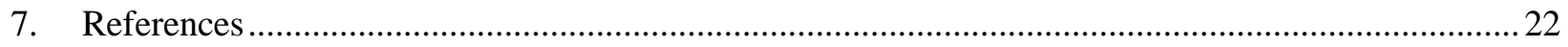




\section{ACKNOWLEDGEMENTS}

The authors would like to acknowledge and express their appreciation to all the following individuals and programs for their review, comments, and support of this report.

\section{DOE Water Power Program}

- Daniel Rabon, Water Power Program Manager

- Tim Welch, Hydropower Program Manager

\section{Biosphere 2}

- John Adams, Deputy Director 


\section{LIST OF FIGURES}

Figure 1. Aerial view of Biosphere 2 and conceptual configuration of solar and m-PSH system (Image courtesy of Google Maps, 2016).

Figure 2. Typical week and weekend energy need at B2. Data points represent the average amount of energy consumed in the prior 15 minutes.

Figure 3. Tariff distribution of average monthly electrical bills.

Figure 4. US solar irradiation (top, map obtained at http://www.nrel.gov/gis/solar.html); 2015 average daily energy use at Biosphere 2 and 2014 average daily solar irradiation in Oracle, AZ (bottom).

Figure 5. Solar irradiation and B2 energy consumption during July (top) and December (bottom).

Figure 6. Representation of a solar plus storage solution sized to enable high energy independence.

Figure 7. Frequency distribution of the required average hourly turbine power of the m-PSH system.

Figure 8. Daily water storage requirement for each reservoir. 12

Figure 9. Combined plot of average B2 load, solar power from a 3.63MW array, and the distribution of solar power between the B2 load, an 820kW m-PSH pump, and the grid for July (left) and December (right). Solar Power to Pump includes losses from pumping and turbine generation.

Figure 10. Approximate commercial solar PV quoted prices, Q1 2016. Adapted from http://www.seia.org/research-resources/solar-industry-data.

Figure 11. Approximate installed cost distribution for the m-PSH portion of a hybrid energy storage system. 16

Figure 12. Approximate cost of installed storage $(\$ / \mathrm{kWh})$ for various electrical energy storage technologies.

Figure 13. Financial sensitivity to various economic parameters. 


\section{LIST OF TABLES}

Table 1. 2015 monthly energy consumption statistics at B2. ........................................................... 3

Table 2. 2014 monthly solar irradiation statistics near Oracle, AZ ......................................................6

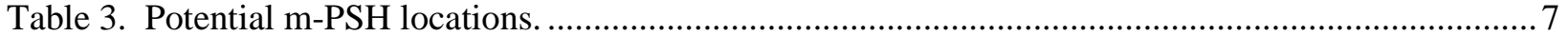

Table 4. Comparison of average B2 energy needs and solar generation potential for a $3.63 \mathrm{MW}$ array. Cells are colored by the ratio of on-peak storable energy to off-peak energy need. Note that solar energy available to pump would be subject to an $81 \%$ roundtrip efficiency loss before it could be applied to meet the off-peak energy need.

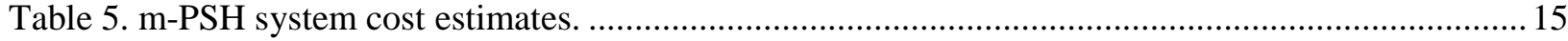

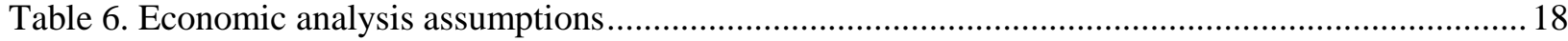

Table 7. Economic indicators for a hybrid energy storage and generation system with projected theoretical cost reductions. 


\section{EXECUTIVE SUMMARY}

In this study, the preliminary feasibility of a hybrid solar and modular pumped storage system designed for high energy independence at Biosphere 2 is assessed. The system consists of an array of solar photovoltaic panels that generate electricity during the day to power both Biosphere 2 and a pump that sends water through a pipe to a tank at a high elevation. When solar power is not available, the water is released back down the pipe towards a tank at a lower elevation, where it passes through a hydraulic water turbine to generate hydroelectricity to power Biosphere 2. The hybrid system is sized to generate and store enough energy to enable Biosphere 2 to operate without a grid interconnection on an average day.

An analysis of average daily energy needs at Biosphere 2 in 2015 indicated a solar array with 3.63 MW of installed capacity coupled to a modular pumped storage hydropower system with a $463 \mathrm{~kW}$ turbine, an $825 \mathrm{~kW}$ pump, and 4,000,000 gallons of water storage (roughly equivalent to $5,500 \mathrm{kWh}$ at $492 \mathrm{ft}$ of net head) would enable high energy independence. The combined initial capital cost of this hybrid system is estimated at $\$ 12,900,000$, nearly evenly distributed between solar and modular pumped storage hydropower systems. Using total hybrid generating capacity of 4,090 kW and storage capacity of 5,500 kWh, the normalized initial capital cost is estimated at $\$ 3,144 / \mathrm{kW}$ and $\$ 2,338 / \mathrm{kWh}$, respectively. The largest cost driver for the system is the water storage tanks - two of them are needed in the modular pumped storage system and together they account for nearly a quarter of the total hybrid system cost.

Using avoidance of the current annual electricity bill and the sale of excess solar power as benefits of the hybrid system, an economic analysis indicated the benefit-cost ratio of the hybrid system is approximately 0.72 . A sensitivity analysis showed that initial capital costs need to be reduced to $65 \%$ to $73 \%$ of their current levels before the benefit-cost ratio rises above 1.0 .

This work demonstrated that it is technically feasible to construct a hybrid solar driven modular pumped storage facility using existing technologies; however, the major impediment to project realization is cost. Potential future research directions include (1) a focus on using alternatives to water storage tanks, such as a simple excavated and lined basin, which could possibly lower storage costs, (2) smaller solar and storage capacities could be explored in combination with potential future demand charge and tariff increases to quantify the economic feasibility of a hybrid system used for demand charge management, and (3) quantification of the academic and social benefit of a novel hybrid renewable energy generation and storage system, which, if included in the economic assessment, could increase the overall feasibility of the project. 



\section{Introduction}

Biosphere 2 (B2) is a unique large-scale Earth systems science research facility situated near the city of Oracle, AZ. The facility was commissioned in 1991 as a closed ecological system, completely sealed from the external environment, with the purpose of exploring the viability of sustaining human life within an artificially controlled ecosystem. The unique biomes maintained within B2 - a $1,900 \mathrm{~m}^{2}$ rainforest, an $850 \mathrm{~m}^{2}$ ocean, a $450 \mathrm{~m}^{2}$ mangrove wetlands, a $1,300 \mathrm{~m}^{2}$ savannah grassland, a $1,400 \mathrm{~m}^{2}$ fog desert, and a $2,500 \mathrm{~m}^{2}$ agricultural system - are continuously regulated through various heating, cooling, and electrical systems. In keeping with their mission of self-sustainability, B2 is currently exploring the possibility of utilizing a hybrid solar photovoltaic (PV) array coupled with a modular pumped storage hydropower (m-PSH) system generate and store renewable energy.

Arizona receives some of the highest annual average solar irradiation in the US, and thus it is an ideal state for a PV solar power system. A significant impediment to onsite solar generation is the inability to store solar energy for use when solar resources are inadequate (cloudy days) or unavailable (at night). B2 is a large energy consumer, and power is required around the clock to maintain critical support for biomes and other research projects. Any solution that enables selfsustainable energy management will require a means to store energy for use at all times.

The terrain surrounding B2 provides a unique opportunity to employ an m-PSH system for solar energy storage. Pumped storage is a fairly mature energy storage technology that utilizes a mechanical pump to push water from a lower elevation to a higher elevation during times when excess energy is available. When energy is required at a later time, water is released from the upper elevation, through a penstock, down to a lower elevation where a hydraulic water turbine is used to generate energy. Pumped storage plants are highly desired for their long useful life, reliable provisioning of energy services, ability to provide rapid response capabilities to the grid, and load balancing to assist the integration of intermittent renewable generators. Conventional plants have been deployed throughout the world at large scales (>100MW), however, deployment at small scales has been deterred by high project costs (Witt et al., 2015).

\subsection{Purpose and scope}

The purpose of this report is to assess the preliminary feasibility of a hybrid solar and modular pumped storage system at B2. A system design is proposed that uses a solar array to meet the daily energy demands of B2. The solar array is oversized such that power generated in excess of the hourly B2 load will be used to pump water through a conveyance to a reservoir at a high elevation. When solar power is not available, the water will be released back down the conveyance and through a hydraulic water turbine to generate hydroelectric power. The hybrid system is designed to enable high energy independence - self-sufficient power generation on an average winter day, with surplus generation in summer months. Preliminary cost estimates are provided, and a financial analysis characterizes the economic feasibility of the design based on projected energy cost savings and the sale of surplus solar power. 


\section{Study Area and Site Characterization}

Biosphere 2 is located near Oracle, AZ in mountainous terrain that provides favorable topography for pumped storage hydro (Figure 1). B2 owns some of the land adjacent to the main campus where a solar PV array could be sited. The remaining land is controlled by CDO Ventures, a company owned by an original investor in B2 and a current financial contributor to the facility. CDO Ventures has a close relationship with B2 and is amenable to discussing using their land for an m-PSH system.

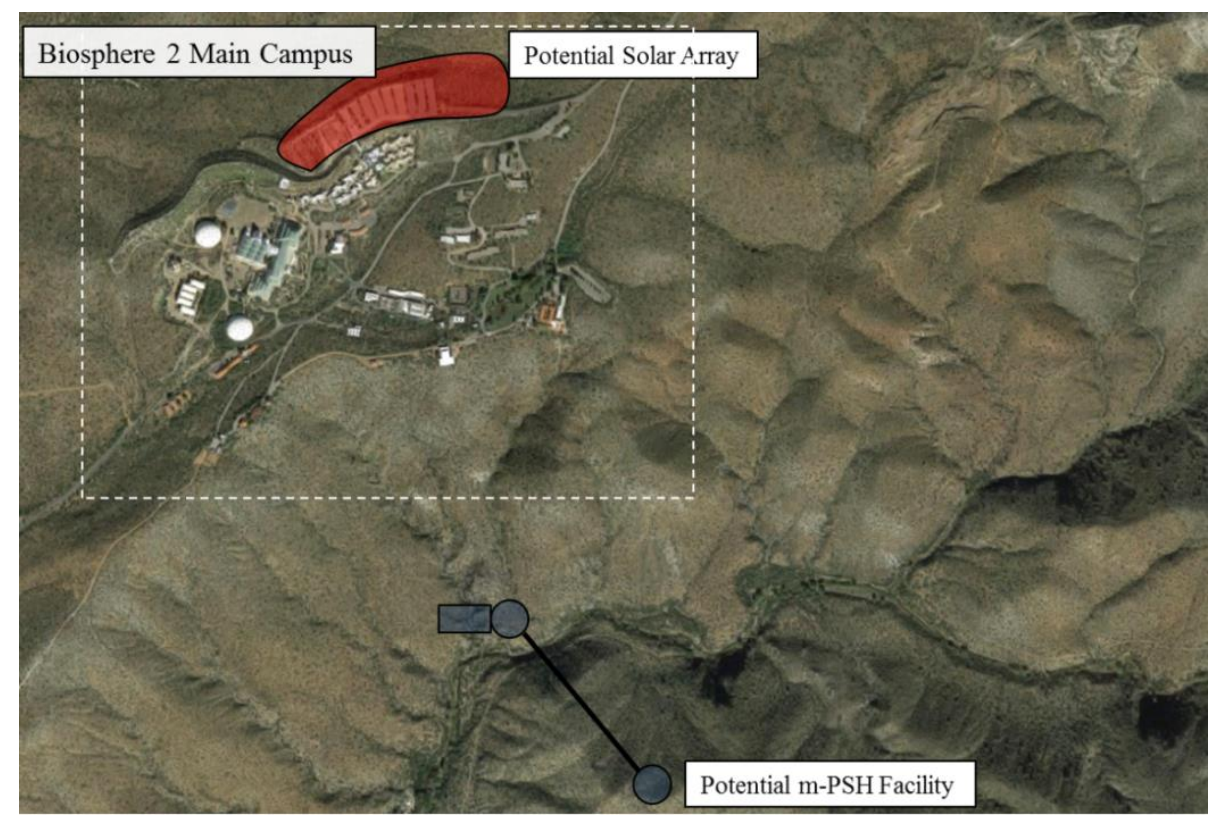

Figure 1. Aerial view of Biosphere 2 and conceptual configuration of solar and m-PSH system (Image courtesy of Google Maps, 2016).

A site visit was carried out in June 2016 to assess the potential for m-PSH at the Biosphere 2 campus, to obtain energy consumption data, and to discuss existing and future tariff structures. Solar irradiation data for Oracle, AZ was obtained from the NREL National Solar Radiation Data Base (NSRDB) ${ }^{1}$.

\subsection{B2 energy and energy cost dynamics}

An understanding of peak, off-peak, and hourly energy demand at B2 is necessary to size a hybrid energy storage system. The average daily energy demand at B2 characterized by month is shown in Figure 2. In the cooler winter months, hourly energy demand remains steady at $400 \mathrm{kWh}$ throughout the day. In warmer months, a greater need for temperature control drives peak energy demand nearly twice as high, resulting in a conventional bell shaped demand curve. Off-peak demand remains elevated over cooler months due to the strategic powering of chillers at night when gross energy demand is low. The chillers, operated to remove heat from cooling water systems, are timed to ramp down in the early morning hours right before the need for cooling water arises. This dynamic is most readily observed during the week in October, when the energy curve ramps up at 20:00 and back down at 04:00.

\footnotetext{
${ }^{1}$ http://rredc.nrel.gov/solar/old_data/nsrdb/
} 

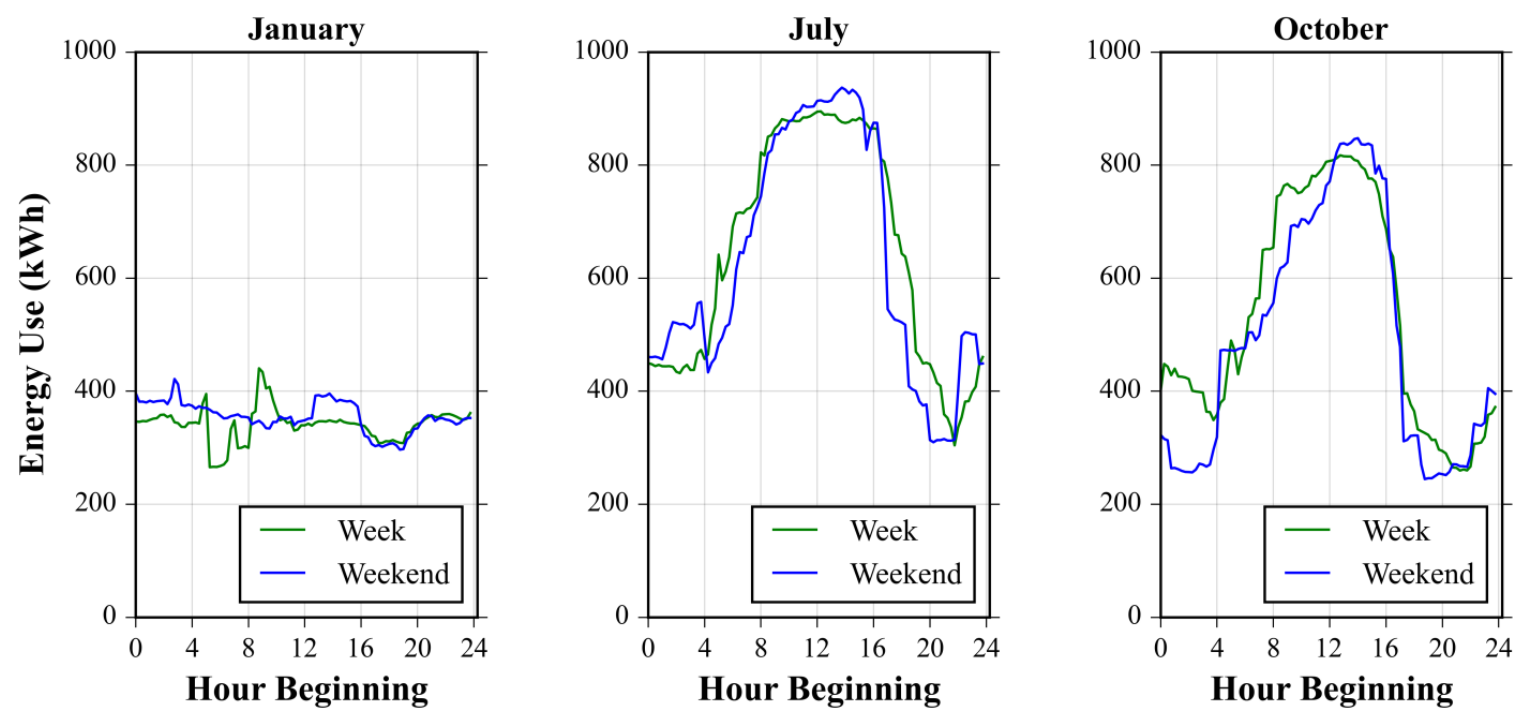

Figure 2. Typical week and weekend energy need at B2. Data points represent the average amount of energy consumed in the prior 15 minutes.

A better understanding of monthly energy consumption dynamics is gained by analyzing average and maximum values of key B2 energy and power statistics (Table 1). Annual energy consumption is approximately 4.3 million $\mathrm{kWh}$. Average daily energy need varies between a yearly minimum of $8,274 \mathrm{kWh}$ in January to a maximum of $15,425 \mathrm{kWh}$ in July. The maximum daily energy need, i.e., the day with the greatest amount of energy consumed in a given month, is between $3,000 \mathrm{kWh}$ and $5,000 \mathrm{kWh}$ greater than the average daily energy need. Average and maximum peak power demand show a similar dynamic with a $200 \mathrm{~kW}$ to $600 \mathrm{~kW}$ spread for any given month. This difference is important for two reasons: (1) a system sized to meet the total energy need of B2 must satisfy the maximum daily energy need and power demand, and (2) large seasonal differences in energy and power dynamics may require solar and m-PSH capabilities that are underutilized in certain months.

Table 1. 2015 monthly energy consumption statistics at B2.

\begin{tabular}{c|c|c|c|c|c|c|c|c|c|c|c|c}
\hline & Jan & Feb & Mar & Apr & May & Jun & Jul & Aug & Sep & Oct & Nov & Dec \\
\hline $\begin{array}{c}\text { Average Daily } \\
\text { Energy Need } \\
\text { (kWh) }\end{array}$ & 8,274 & 9,948 & 11,172 & 10,717 & 11,847 & 15,342 & 15,425 & 15,096 & 14,172 & 12,514 & 10,036 & 9,060 \\
\hline $\begin{array}{c}\text { Max Daily } \\
\text { Energy Need } \\
\text { (kWh) }\end{array}$ & 11,271 & 13,551 & 14,884 & 13,042 & 13,222 & 18,722 & 20,600 & 19,243 & 18,213 & 16,217 & 14,788 & 12,335 \\
\hline $\begin{array}{c}\text { Average } \\
\text { Daily Peak } \\
\text { Power } \\
\text { Demand } \\
\text { (kW) }\end{array}$ & 527 & 711 & 747 & 789 & 827 & 941 & 999 & 950 & 930 & 896 & 741 & 603 \\
\hline $\begin{array}{c}\text { Max Daily } \\
\text { Power }\end{array}$ & 994 & 1,063 & 1,088 & 1,233 & 1,094 & 1,200 & 1,230 & 1,196 & 1,137 & 1,179 & 1,082 & 1,184 \\
\hline $\begin{array}{c}\text { Demand } \\
\text { (kW) }\end{array}$ & & & & & & & & & & & & \\
\hline
\end{tabular}


Energy and power consumption tariffs are based on a three-tiered structure:

Industrial Electric $=\$ 250.00+R_{1} * \sum_{i=0}^{T} E_{i} / 4$, Purchased Power $=R_{2} * \sum_{i=0}^{T} E_{i} / 4$,

Demand Electric $=R_{3} * \max _{i \in T} E_{i}$

where $E_{i}$ is the average $\mathrm{kW}$ supplied during the prior 15-minute period, $T$ is the number of 15 minute periods in the billing window, $R_{1}$ and $R_{2}$ are base electricity rates, and $R_{3}$ is a demand charge rate, applied to the average $\mathrm{kW}$ supplied during the 15-minute period of maximum use during the month. The total monthly electricity bill is the sum of all three rates, which is generally comprised of 50\% Industrial Electric, 20\% Purchased Power, and 20\% Demand Electric (Figure 3).

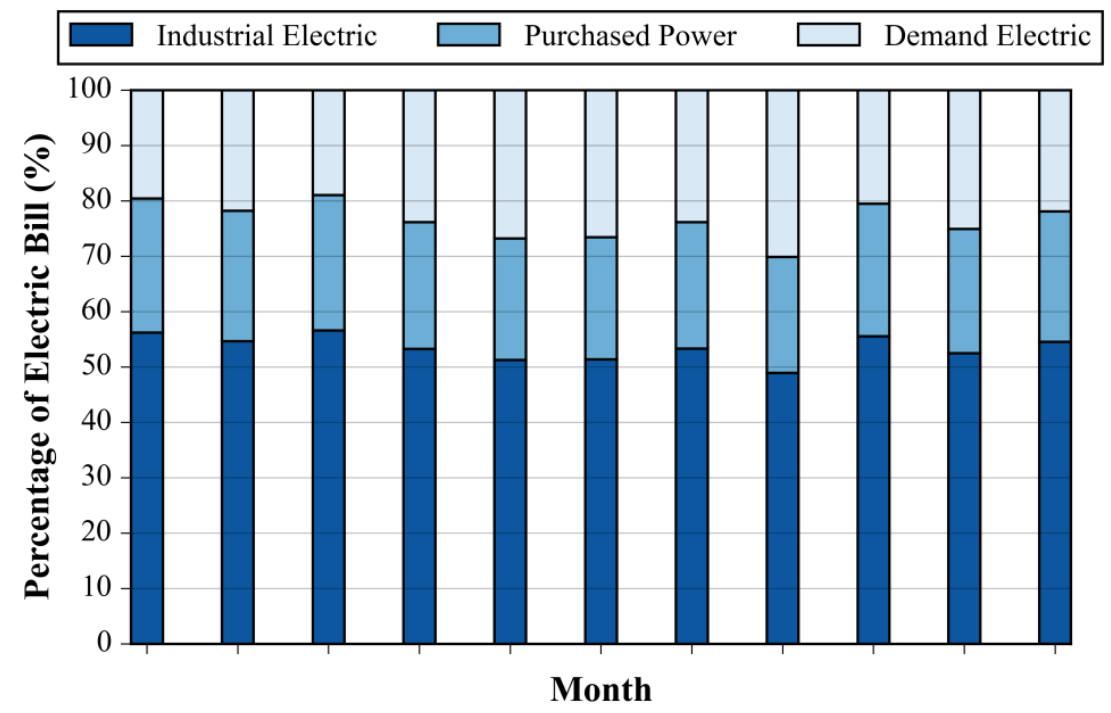

Figure 3. Tariff distribution of average monthly electrical bills.

\subsection{Solar irradiation}

The state of Arizona receives some of the highest irradiation values in the United States, an annual daily average of greater than $6.5 \mathrm{kWh} / \mathrm{m}^{2}$ (Figure 4, top). To assess daily and seasonal variation near B2, hourly solar irradiation values were obtained from the NREL NSRDB ${ }^{2}$ for 2014. Hourly average irradiation values are shown for January, July, and October, overlaid with 2015 hourly average energy use data ${ }^{3}$ from B2 in Figure 4 (bottom). During cooler months, daily average irradiation is roughly half that of warmer months, which will translate into reduced

\footnotetext{
${ }^{2}$ http://rredc.nrel.gov/solar/old_data/nsrdb/

${ }^{3}$ Though two different years are used for irradiation and B2 energy consumption, the average values should not deviate substantially on a yearly basis.
} 
generation and storage capabilities. Peak energy demand is also roughly half that of warmer months, though off-peak demand remains consistent.
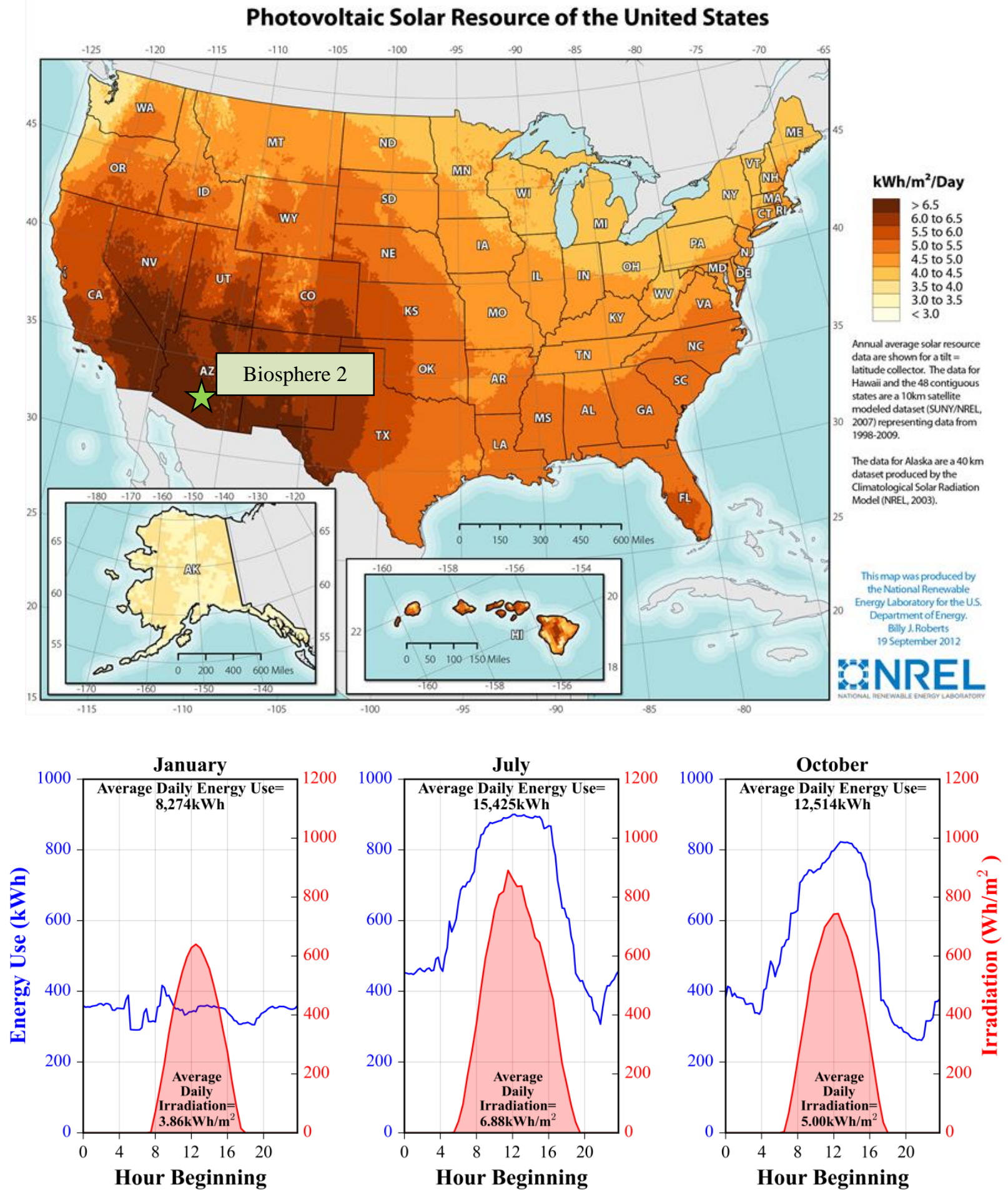

Figure 4. US solar irradiation (top, map obtained at http://www.nrel.gov/gis/solar.html); 2015 average daily energy use at Biosphere 2 and 2014 average daily solar irradiation in Oracle, AZ (bottom). 
The intermittency of solar irradiation and B2 energy consumption on an hourly, daily, and diurnal basis is a large impediment to a solar only energy solution (Table 2). For example, 15minute irradiation and B2 energy consumption intervals over two 10-day periods near Oracle, $\mathrm{AZ}$ are shown in Figure 5. Large hourly variation can be seen during the day in both July and December, where irradiation drops $90 \%$ between 15 -min measurement periods and then recovers. Daily variation is also prevalent, most notably in December when peak irradiation may on any given day be $50 \%$ or less of what was observed the previous day. The intermittency of solar generation can be improved with a hybrid m-PSH storage solution, though greater intermittency will require larger water storage mechanisms and increased project costs.

Table 2. 2014 monthly solar irradiation statistics near Oracle, AZ.

\begin{tabular}{c|c|c|c|c|c|c|c|c|c|c|c|c}
\hline & Jan & Feb & Mar & Apr & May & Jun & Jul & Aug & Sep & Oct & Nov & Dec \\
\hline $\begin{array}{c}\text { Peak } \\
\text { Irradiation } \\
\left(\mathbf{W h} / \mathbf{m}^{\mathbf{2}}\right)\end{array}$ & 713 & 842 & 1,012 & 1,093 & 1,102 & 1,120 & 1,051 & 1,023 & 987 & 906 & 753 & 650 \\
\hline $\begin{array}{c}\text { Average Daily } \\
\text { Irradiation } \\
\left(\mathbf{W h} / \mathbf{~ m}^{\mathbf{2} / \mathbf{d a y})}\right.\end{array}$ & 3,858 & 4,404 & 5,961 & 7,351 & 8,379 & 8,722 & 6,879 & 6,487 & 5,526 & 4,996 & 4,198 & 2,960 \\
\hline
\end{tabular}
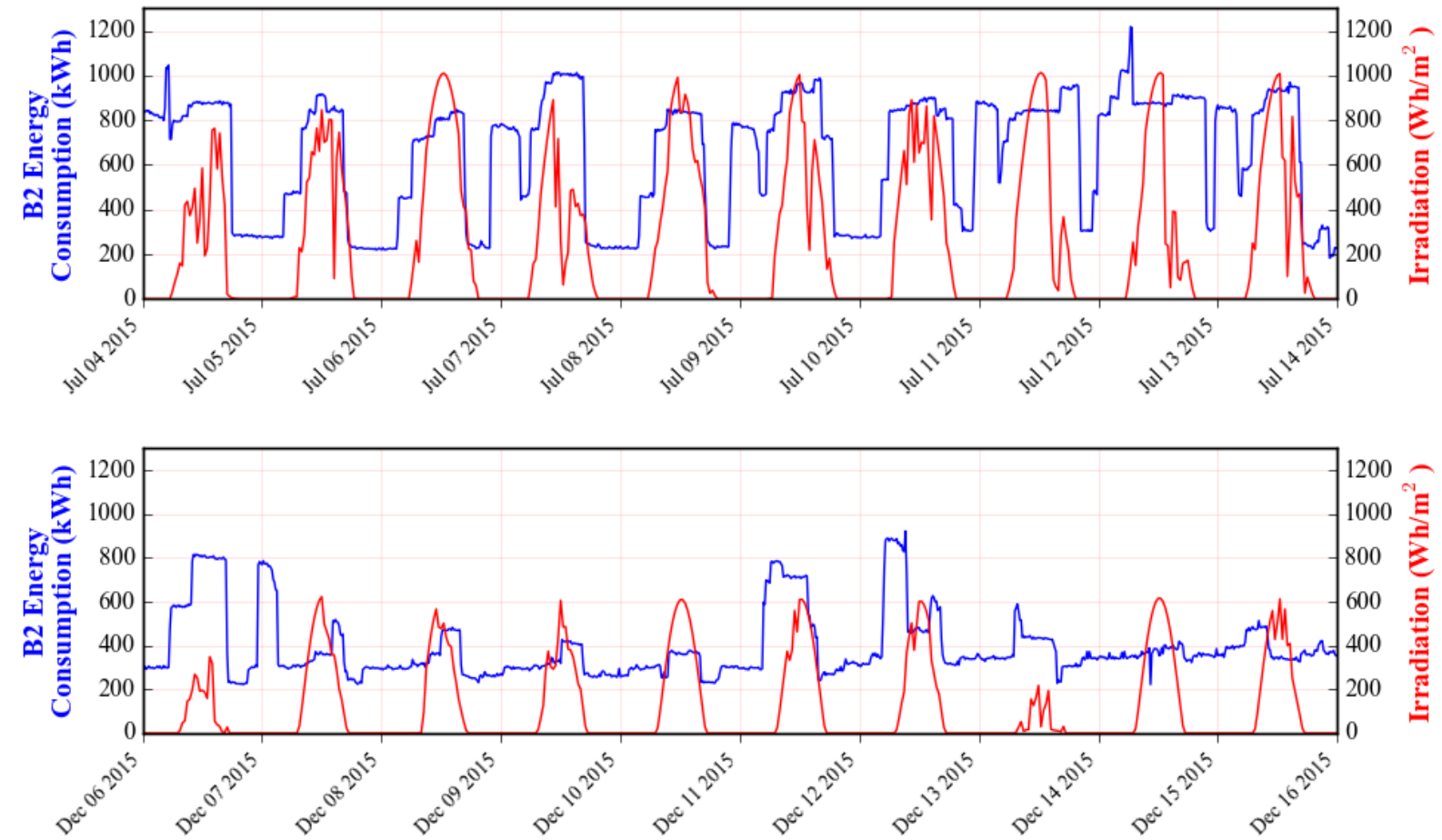

Figure 5. Solar irradiation and B2 energy consumption during July (top) and December (bottom).

The alignment of peak energy consumption and peak solar irradiation is also a design challenge. Consider July 7, 2015 in Figure 5, for example. A large peak in energy consumption occurs in the early morning hours, followed by a slight decline and then another peak that lasts throughout 
mid-day. The mid-day peak can be reduced with solar generation, though a large drop in irradiation for roughly an hour around noon would require the m-PSH system to quickly switch from pumping mode to generating mode, then back to pumping mode. This behavior requires a flexible system, and it requires sufficient water in the upper reservoir to generate power that can briefly offset B2 power consumption. On another day, December 06, 2015, solar irradiation is weak and B2 energy demand is high. It may be desirable to discharge the m-PSH system during the day to offset peak energy consumption rather than charge the system through pumping.

\section{$2.3 \quad$ m-PSH siting}

An initial review of topographical maps was carried out to identify the maximum head available for m-PSH energy generation. Five locations were assessed based on proximity to B2, with elevations, gross head, and penstock length outlined in Table 3. An ideal m-PSH site will have a high gross head, and a low L:H ratio.

Table 3. Potential m-PSH locations.

\begin{tabular}{c|c|c|c|c|c|c}
\hline Option \# & $\begin{array}{c}\text { Upper } \\
\text { Storage } \\
\text { Elevation } \\
(\mathbf{f t})\end{array}$ & $\begin{array}{c}\text { Lower } \\
\text { Storage } \\
\text { Elevation } \\
(\mathbf{f t})\end{array}$ & $\begin{array}{c}\text { Gross } \\
\text { Head }\end{array}$ & $\begin{array}{c}\text { Distance Between } \\
\text { Upper and Lower } \\
\text { Storage } \\
(\mathbf{f t})\end{array}$ & $\begin{array}{c}\text { Average } \\
\text { Slope }\end{array}$ & L:H \\
\hline $\mathbf{f t} / \mathbf{f t})$ & $\mathbf{2 , 7 6 4}$ & 0.183 & 5.452 \\
\hline $\mathbf{1}$ & 3,935 & 3,428 & 507 & 1,699 & 0.221 & 4.530 \\
\hline $\mathbf{3}$ & 3,803 & 3,428 & 375 & 2,633 & 0.165 & 6.06 \\
\hline $\mathbf{4}$ & 3,862 & 3,428 & 434 & 2,542 & 0.174 & 5.751 \\
\hline $\mathbf{5}$ & 3,870 & 3,428 & 442 & 2,411 & 0.191 & 5.241 \\
\hline
\end{tabular}

In order to carry out the preliminary assessment, several important assumptions are made:

- No assessment was made of subsurface conditions - it is assumed the site will require a basic foundation treatment;

- No determination was made of land ownership or land acquisition costs;

- Moderate terrain is assumed that can accommodate standard heavy equipment;

- It is assumed there are no major environmental concerns that would require mitigation. 


\section{Hybrid System Design}

A conceptual design of the hybrid system that utilizes solar and modular pumped storage hydro is presented in (Figure 6). Solar arrays are sized to meet B2 peak power demand and charge mPSH pumps when solar irradiation is available, and the m-PSH system is sized to generate all off-peak power.
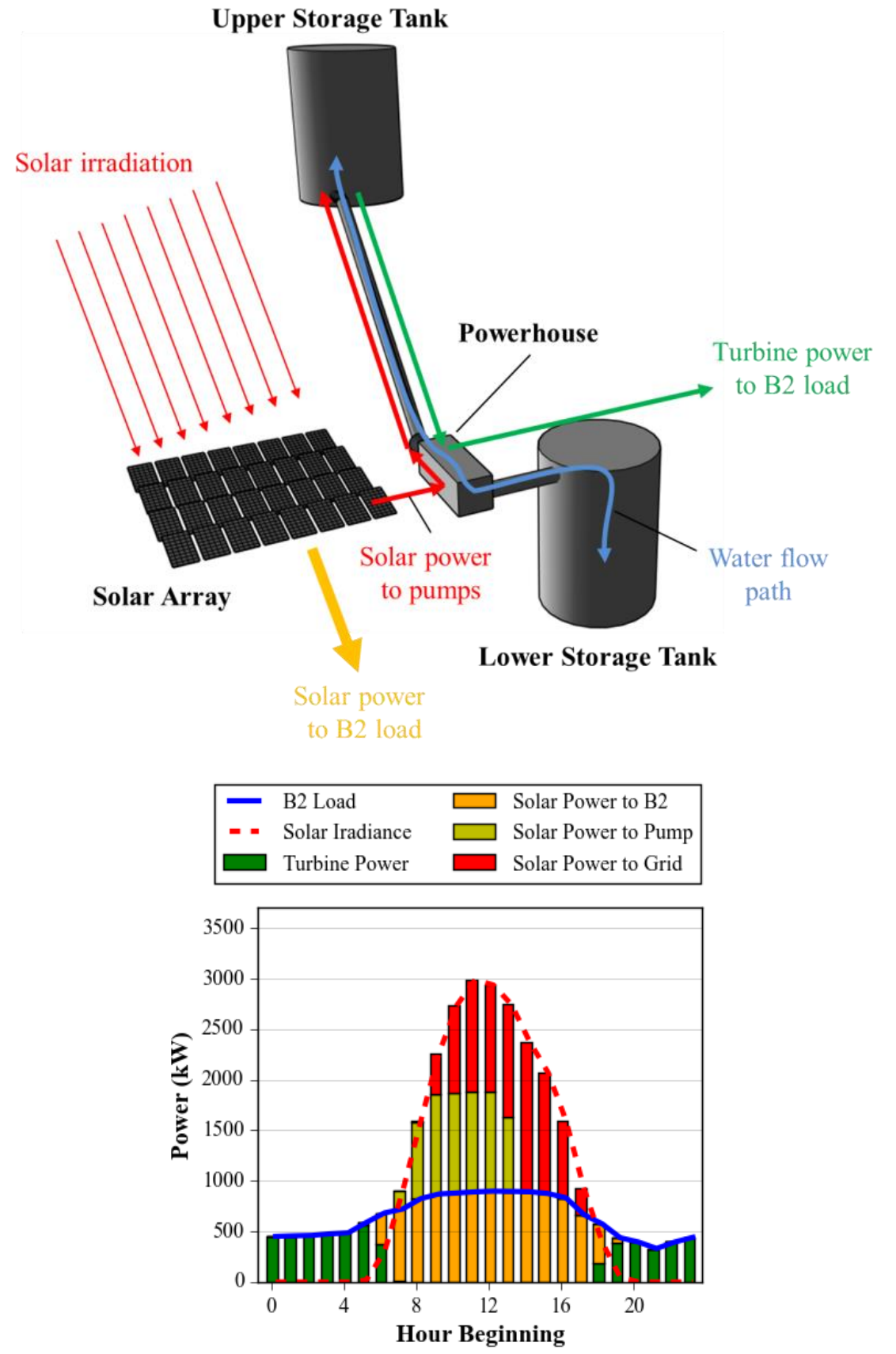

Figure 6. Representation of a solar plus storage solution sized to enable high energy independence.

The three major components of the solar system are (1) an array of solar PV modules, (2) a power inverter, and (3) electrical and structural balance of plant equipment. The four major components of the m-PSH system are (1) upper and lower bolted steel water storage tanks, (2) a 
water conveyance system, consisting of upstream structures (intake, intake gate), diversion structures (penstock pipe and accessories), and valves, (3) a powerhouse, which contains the turbine/generator, pump/motor, and control equipment, and (4) electrical equipment to collect power from the inverter (in solar system) or from generators (in m-PSH system) to deliver power to $\mathrm{B} 2$ or the grid, including a transmission line, transformers, switchyard, and substation.

\subsection{Solar generating capacity estimate}

Solar irradiation data in $\mathrm{kWh} / \mathrm{m}^{2}$ obtained from the NREL SWERA database is converted into solar irradiance, or $\mathrm{kW} / \mathrm{m}^{2}$, for every hour using

$E_{e}=0.25 \sum_{t=1}^{4} H_{e}(t)$,

where $H_{e}$ is solar irradiation in 15 minute increments and $E_{e}$ is hourly solar irradiance. The power output of a solar array is estimated as

$P_{P V}=0.001 * A_{P V} E_{e} \eta_{P V}$

where $P_{P V}$ is the power output of the solar array in $\mathrm{kW}, A_{P V}=$ area of solar collection in $\mathrm{m}^{2}, E_{e}$ is solar irradiance in $\mathrm{W} / \mathrm{m}^{2}$, and $\eta_{P V}=$ efficiency of a solar module. For example, assuming a module efficiency of $18 \%$, a total solar collection area of roughly $6,500 \mathrm{~m}^{2}$ is needed to produce a maximum output of $1,230 \mathrm{~kW}$ when solar irradiance $=1,051 \mathrm{~W} / \mathrm{m}^{2}$.

Excess solar energy is used to power a pump/motor unit, which is assumed to be $90 \%$ efficient. For every $1 \mathrm{kWh}$ of solar energy delivered to the m-PSH system, $0.9 \mathrm{kWh}$ is stored as useful energy. Similarly, the turbine/generator unit is assumed to be $90 \%$ efficient, and the $0.9 \mathrm{kWh}$ of stored energy is converted to $0.81 \mathrm{kWh}$ of usable energy. Mathematically, storable and usable energy are represented as

$E_{\text {storable }}=\eta_{\text {Pump }} * \int_{0}^{24} a b s\left[\min \left\{0, P_{P V}(t)-B 2(t)\right\}\right] d t$,

$E_{\text {usable }}=\eta_{\text {Generation }} * E_{\text {storable }}$,

where $E_{\text {storable }}=$ solar energy stored in the m-PSH system, $\eta_{\text {Pump }}=$ average efficiency of the pump(s) system (motor and pump unit(s)), B2(t) = hourly load in $\mathrm{kW}, P_{P V}(\mathrm{t})=$ hourly solar power output in $\mathrm{kW}, E_{\text {usable }}=$ stored solar energy that can be used to offset off-peak B2 load, and $\eta_{\text {Generaiton }}=$ average efficiency of the turbine(s) system (turbine and generator unit(s)).

A comparison of average off-peak energy need and usable energy generated from a 3.63MW shows the seasonal variation in energy consumption and solar irradiation (Table 4). Monthly average off-peak energy needs can be met throughout the year by $3.63 \mathrm{MW}$ of installed solar capacity. Overall solar capacity is determined by the month of December, where solar irradiation is at an annual minimum, and a larger array is necessary to capture enough energy during the day which can be stored and used at night. During the months of April, May, and June, nearly $4 \mathrm{x}$ the average daily off-peak energy need is generated as usable energy. This additional energy could be stored, or if a commercial agreement is arranged it could be sold back 
to the utility to help offset system costs. An installed solar capacity of $3.63 \mathrm{MW}$ is thus assumed for the system.

Table 4. Comparison of average $\mathrm{B} 2$ energy needs and solar generation potential for a 3.63 MW array. Cells are colored by the ratio of on-peak storable energy to off-peak energy need. Note that solar energy available to pump would be subject to an $81 \%$ roundtrip efficiency loss before it could be applied to meet the off-peak energy need.

\begin{tabular}{|c|c|c|c|c|c|c|c|c|c|c|c|c|c|}
\hline & & Jan & Feb & Mar & Apr & May & Jun & Jul & Aug & Sep & Oct & Nov & Dec \\
\hline & $\begin{array}{c}\text { B2 average } \\
\text { daily energy } \\
\text { need } \\
(\mathbf{k W h})\end{array}$ & 8,274 & 9,948 & 11,172 & 10,717 & 11,847 & 15,342 & 15,425 & 15,096 & 14,172 & 12,514 & 10,036 & 9,060 \\
\hline \multirow{4}{*}{$\begin{array}{c}\text { 3.63MW } \\
\text { solar array }\end{array}$} & $\begin{array}{c}\text { On-peak solar } \\
\text { energy } \\
\text { generated } \\
(\mathbf{k W h})\end{array}$ & 13,402 & 15,298 & 20,708 & 25,536 & 29,109 & 30,300 & 23,896 & 22,536 & 19,196 & 17,357 & 14,584 & 10,284 \\
\hline & $\begin{array}{c}\text { On-peak solar } \\
\text { energy } \\
\text { consumed } \\
(\mathbf{k W h})\end{array}$ & 3,343 & 5,079 & 6,333 & 6,787 & 7,877 & 10,222 & 9,999 & 9,488 & 8,741 & 7,477 & 5,274 & 4,047 \\
\hline & $\begin{array}{c}\text { Solar energy } \\
\text { available to } \\
\text { pump or send to } \\
\text { grid } \\
(\mathrm{kWh}) \\
\end{array}$ & 10,059 & 10,219 & 14,375 & 18,749 & 21,232 & 20,078 & 13,897 & 13,048 & 10,455 & 9,880 & 9,310 & 6,237 \\
\hline & $\begin{array}{l}\text { Remaining off- } \\
\text { peak energy } \\
\text { need }(\mathrm{kWh})\end{array}$ & 4,930 & 4,870 & 4,839 & 3,929 & 3,970 & 5,120 & 5,425 & 5,608 & 5,431 & 5,037 & 4,762 & 5,014 \\
\hline
\end{tabular}

\section{2 m-PSH capacity estimates}

The m-PSH system consists of six major components: upper storage tank, lower storage tank, water conveyance, powerhouse, electro-mechanical equipment, and electrical equipment. Upper and lower water storage tanks store a volume of water proportional to the energy storage needs of B2, and a steel penstock connects them. The pump/motor and turbine/generator are sized to charge and discharge throughout the day. Pumping will occur when excess solar is available, and generation will take place when excess solar is not available (corresponding to the yellow and green shaded sections, respectively, of Figure 6).

Major assumptions include:

- No seismic or subsurface issues that require extensive mitigation;

- Relatively simple access for construction

\subsection{1 m-PSH turbine capacity estimates}

To estimate turbine installed capacity, B2 average off-peak power demand is assessed on an hourly basis. A frequency distribution of average hourly required turbine power generation, i.e., the amount of power that must be discharged from the m-PSH system to meet the B2 load, for the entire year shows a turbine capacity between $250 \mathrm{~kW}$ and $450 \mathrm{~kW}$ would satisfy the hourly power requirement $71 \%$ of the time (Figure 7). For simplicity, a single Pelton turbine is assumed 
that can operate within a range of $250 \mathrm{~kW}-550 \mathrm{~kW}$, with an installed capacity of $463 \mathrm{~kW}$ at peak efficiency of $90 \%$.

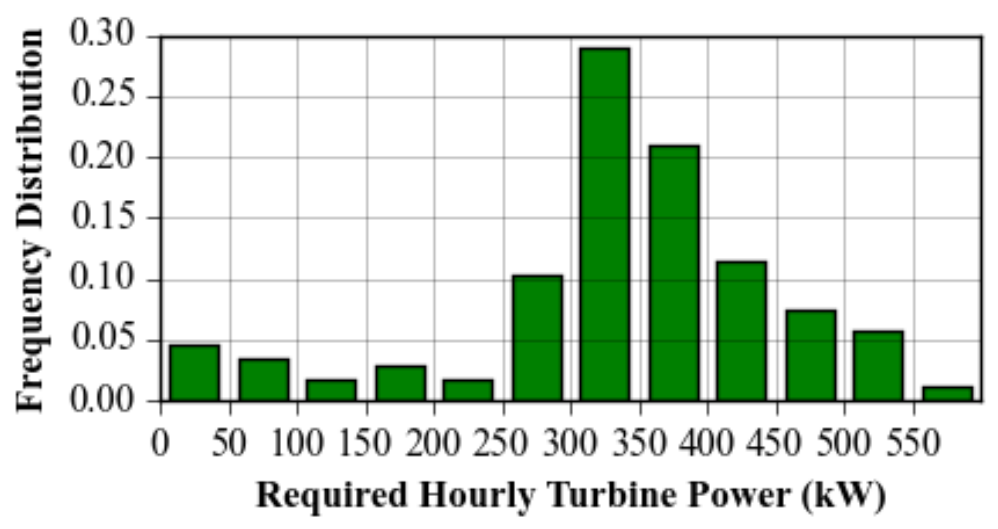

Figure 7. Frequency distribution of the required average hourly turbine power of the m-PSH system.

The turbine power delivered to the meet the B2 load is governed by the hydropower equation,

$$
P_{T}=\frac{Q H \eta_{\text {Generation }}}{11.8},
$$

where $P_{T}$ is power delivered from the turbine/generator in $\mathrm{kW}, Q$ is the flow rate through the turbine in $\mathrm{ft}^{3} / \mathrm{s}, H$ is the net head acting on the turbine blades in $\mathrm{ft}, \eta_{\text {Generate }}$ is the efficiency of the turbine/generator unit. This equation can be rearranged to estimate the flowrate $Q$ by assuming a unit efficiency of $90 \%$ and a net head of $492 \mathrm{ft}$, derived using a gross head of $507 \mathrm{ft}$ (Option \#1 from Table 3) with penstock head losses of $3 \%$. The result is an average design flow of $12 \mathrm{cfs}$.

\subsection{2 m-PSH water storage tank capacity estimates}

The remaining off-peak energy need from Table 4 represents the energy in $\mathrm{kWh}$ that must be stored during on-peak hours to meet the B2 load when solar is unavailable. Sizing the m-PSH system to the largest off-peak energy need results in a storage requirement of roughly 5,600 $\mathrm{kWh}$, or roughly 12.5 hours of storage for a turbine generating at an average capacity of $450 \mathrm{~kW}$. The total volume of water required per reservoir per month is then estimated as

$$
V_{\text {Storage }}=Q * 3600 * 12.5 \text {, }
$$

where $V_{\text {storage }}$ is water storage in $\mathrm{ft}^{3}$. Storage between 374,000 to $534,000 \mathrm{ft}^{3}(2.8$ and 4 million gallons) is necessary on a monthly basis. Total storage of 4 million gallons per tank is chosen for the hybrid system. 


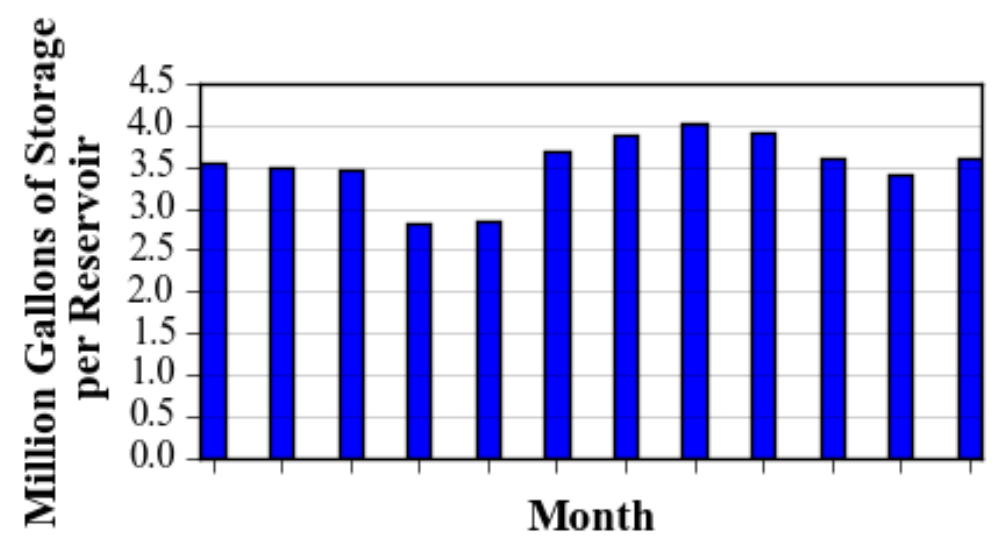

Figure 8. Daily water storage requirement for each reservoir.

\subsection{3 m-PSH pump capacity estimates}

The capacity of the pump is chosen next after several key considerations:

- The hours available for pumping are generally fewer than the hours required for generation, meaning the pump capacity may be substantially larger than the turbine capacity;

- To save costs, the pump must operate using the same penstock as the turbine;

- The maximum pump size is determined by the excess solar in winter months;

- The pump may need to be located in a pit below the powerhouse to ensure sufficient suction head for operation. This is not explicitly accounted for in cost or design assumptions.

The pump is optimized to fully charge the system across the longest number of hours possible based on the month with the lowest available solar power surplus. This allows for the smallest possible pump capacity that can fully charge the system with solar power. A small pump capacity is desired to match the turbine capacity as they share a conveyance with a fixed diameter, and volumetric flow rates in both directions must be similar.

An optimum pump capacity of $820 \mathrm{~kW}$ is estimated to cover the average daily storage need for each month. The dynamics of this size pump on the hybrid system are shown in Figure 9, which compares turbine power, solar power to B2, solar power to pumps, and solar power to the grid for July and December. In summer months, the m-PSH system is quickly charged, and a large amount of surplus solar is available that can be fed back into the grid. In winter months when solar power potential is reduced, the pumps consume nearly all of the solar power generated. 

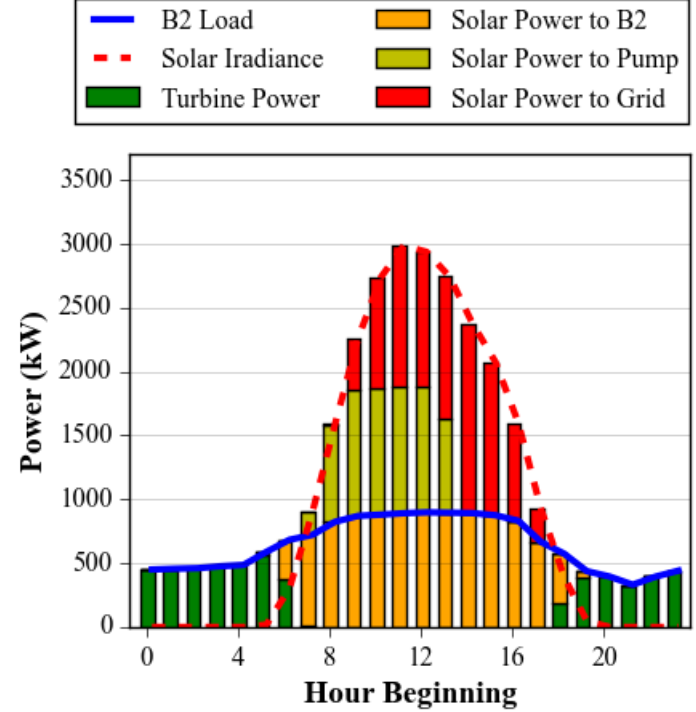
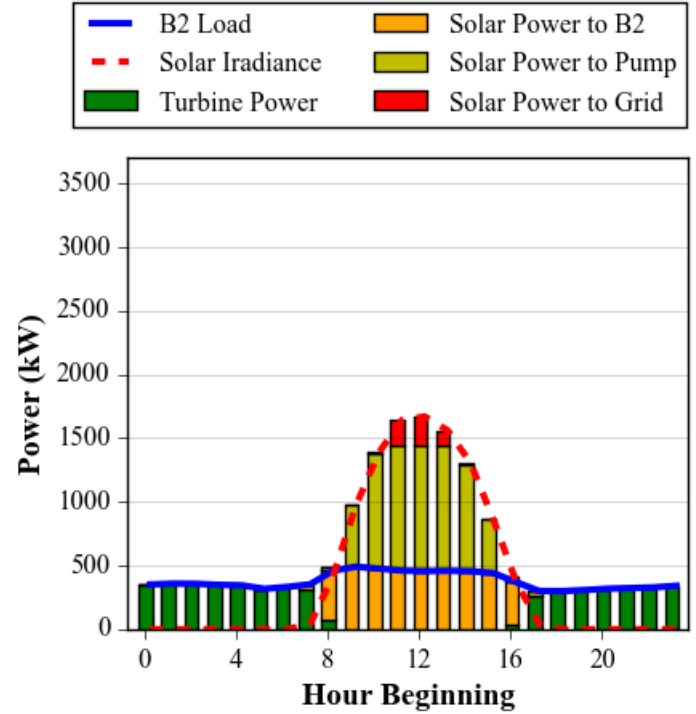

Figure 9. Combined plot of average B2 load, solar power from a 3.63MW array, and the distribution of solar power between the $B 2$ load, an $820 \mathrm{~kW}$ m-PSH pump, and the grid for July (left) and December (right). Solar Power to Pump includes losses from pumping and turbine generation.

\subsection{4 m-PSH water conveyance capacity estimates}

Based on the design flow of $12 \mathrm{cfs}$, a steel penstock with a design capacity of $18 \mathrm{cfs}$ is proposed. Penstock diameter is sized at $1.5 \mathrm{ft}$ diameter, assuming a head loss of $2 \%$ over the gross head of $507 \mathrm{ft}$. 


\section{Hybrid System Cost}

Costs are estimated for the solar array and m-PSH systems separately.

\subsection{Solar array}

No explicit design of a solar system is offered, rather, unit based estimates are used to estimate solar system costs. Recent market analysis of solar turnkey installed costs ${ }^{4}$ shows commercial installations trending below $\$ 2.00 /$ watt-dc, with the majority of project costs distributed between PV modules and the soft costs of direct labor, engineering, and supply chain, overhead, and margin. Solar prices have dropped $70 \%$ since 2006, and continue to decline on a year-on-year basis (Chung et al., 2015). It is assumed that a solar array could be installed for roughly $\$ 1.80 /$ watt-dc, or $\$ 6,534,000$ for a $3.63 \mathrm{MW}$ system.
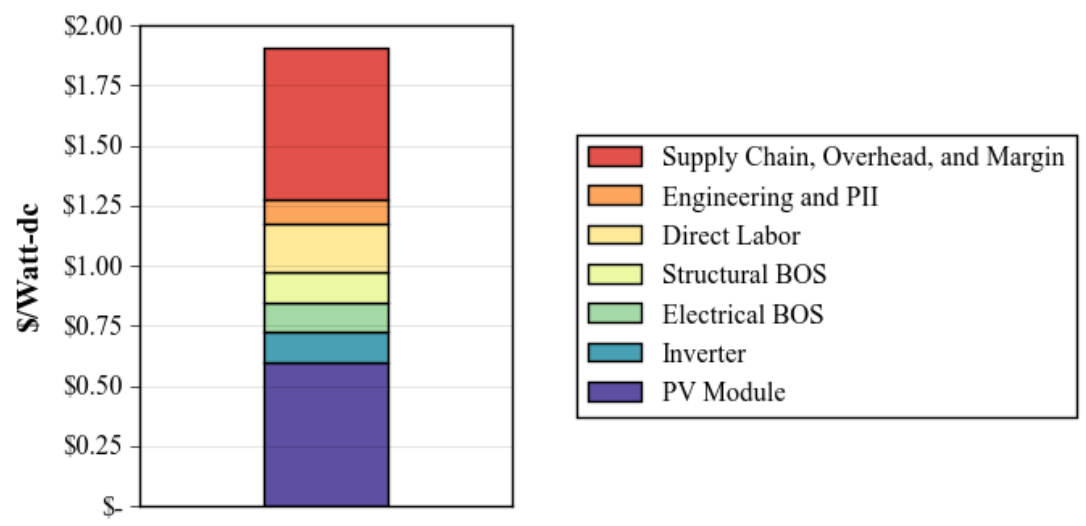

Figure 10. Approximate commercial solar PV quoted prices, Q1 2016. Adapted from http://www.seia.org/research-resources/solar-industry-data.

Major assumptions include:

- No significant electrical infrastructure requirements to link solar output to B2 or the grid;

\section{2 m-PSH}

The m-PSH system installed capital costs consist of seven major categories: upper storage reservoir, lower storage reservoir, conveyance, powerhouse, electro-mechanical equipment, electrical equipment, and development costs. A parametric and engineering based approach is used to predict the costs of the m-PSH system, similar to that employed by O'Connor et al. (2015) for small hydropower cost modeling. A full list of m-PSH cost assumptions and design assumptions and methodology can be found in a companion report (Witt et al., 2016), while a full breakdown of estimated system costs is shown in Table 5.

Total m-PSH initial capital cost is estimated at $\$ 6,326,000$, or $\$ 13,656 / \mathrm{kW}$ based on $463 \mathrm{~kW}$ of generating capacity.

\footnotetext{
${ }^{4}$ http://www.seia.org/research-resources/solar-industry-data
} 
Table 5. m-PSH system cost estimates.

\begin{tabular}{|c|c|c|c|c|c|}
\hline Category & Unit & Quantity & Rate & $\$$ & $\$ / \mathbf{k W}$ \\
\hline 1. Civil Works & & & & $3,164,264$ & 6,836 \\
\hline 1.1 Upper Storage & gallons & $4,000,000$ & 0.34 & $1,371,587$ & 2,963 \\
\hline 1.2 Lower Storage & gallons & $4,000,000$ & 0.34 & $1,371,587$ & 2,963 \\
\hline 1.3 Site Access Road & miles & & & 28,659 & 62 \\
\hline 1.4 Water Conveyances (1.5ft diameter) & $\mathrm{ft}$ & 2,764 & 113 & 305,169 & 659 \\
\hline 1.5 Powerhouse & $\mathrm{ft}^{2}$ & 403 & 200 & 80,683 & 174 \\
\hline 2. Electro-Mechanical Equipment* & & & & $\mathbf{1 , 0 3 5 , 7 7 2}$ & 2,238 \\
\hline 2.1 Turbine/Generator & $\mathrm{kW}$ & 463 & $1,468.58$ & 591,103 & 1,277 \\
\hline 2.2 Pump/Motor & $\mathrm{kW}$ & 825 & 369.91 & 265,371 & 573 \\
\hline 2.3 Ancillary Plant Electrical Systems & & & $15 \%$ & 96,545 & 209 \\
\hline 2.4 Ancillary Plant Mechanical Systems & & & $15 \%$ & 82,753 & 179 \\
\hline 3. Electrical Infrastructure ${ }^{* *}$ & & & & 158,838 & 343 \\
\hline 3.1 Transmission Line & miles & 0.5 & 132,712 & 57,701 & 125 \\
\hline 3.2 Transformers, Switchyard, and Substation & $\mathrm{kW}$ & 825.00 & 140.27 & 100,625 & 214 \\
\hline 3.3 Electrical Infrastructure Installation & & & $15 \%$ & 13,125 & 32 \\
\hline Pre-Contingency Subtotal (Category $1+2+3$ ) & & & & 4,358,885 & $\mathbf{9 , 4 1 7}$ \\
\hline Contingency & \multicolumn{3}{|c|}{$20 \%$ of $1,15 \%$ of 2 and 3} & 810,729 & 1,752 \\
\hline Subtotal & & & & $5,163,024$ & 11,154 \\
\hline 4. Engineering and Construction Management & & & $15 \%$ & $\mathbf{7 7 4 , 4 5 4}$ & 1,673 \\
\hline 5. Environmental/Regulatory Compliance $* * *$ & LS & 50,000 & 1 & $\mathbf{5 0 , 0 0 0}$ & 108 \\
\hline 6. Development & Estimate & & & 338,058 & 730 \\
\hline 6.1 Permitting, Licensing, and Site Acquisition & & & & 238,197 & 515 \\
\hline 6.2 Initial Engineering & & & & 99,862 & 216 \\
\hline Total Initial Capital Cost & & & & $6,325,536$ & 13,666 \\
\hline
\end{tabular}

* Ancillary plant electrical or mechanical system cost corresponds to $15 \%$ of turbine and generator cost

** Installation is $15 \%$ of Transformers, Switchyard, and Substation

$* * * \mathrm{LS}=$ lump sum 
Total initial capital cost (ICC) estimates are shown by category in Figure 11. The largest category cost is civil works at $50 \%$ of ICC, with the bulk of that expense going towards upper and lower water storage tanks. Electro-mechanical and electrical equipment are estimated to be $20 \%$ of total ICC, while contingencies and soft costs associated with development comprise the remaining 30\% of total ICC. The cost in terms of $\$ / \mathrm{kW}$ and $\$ / \mathrm{kWh}$ is substantially larger than conventional pumped storage plants (MWH, 2009; Lazards, 2015), reflecting the challenges associated with smaller scale development and the lack of economies of scale.

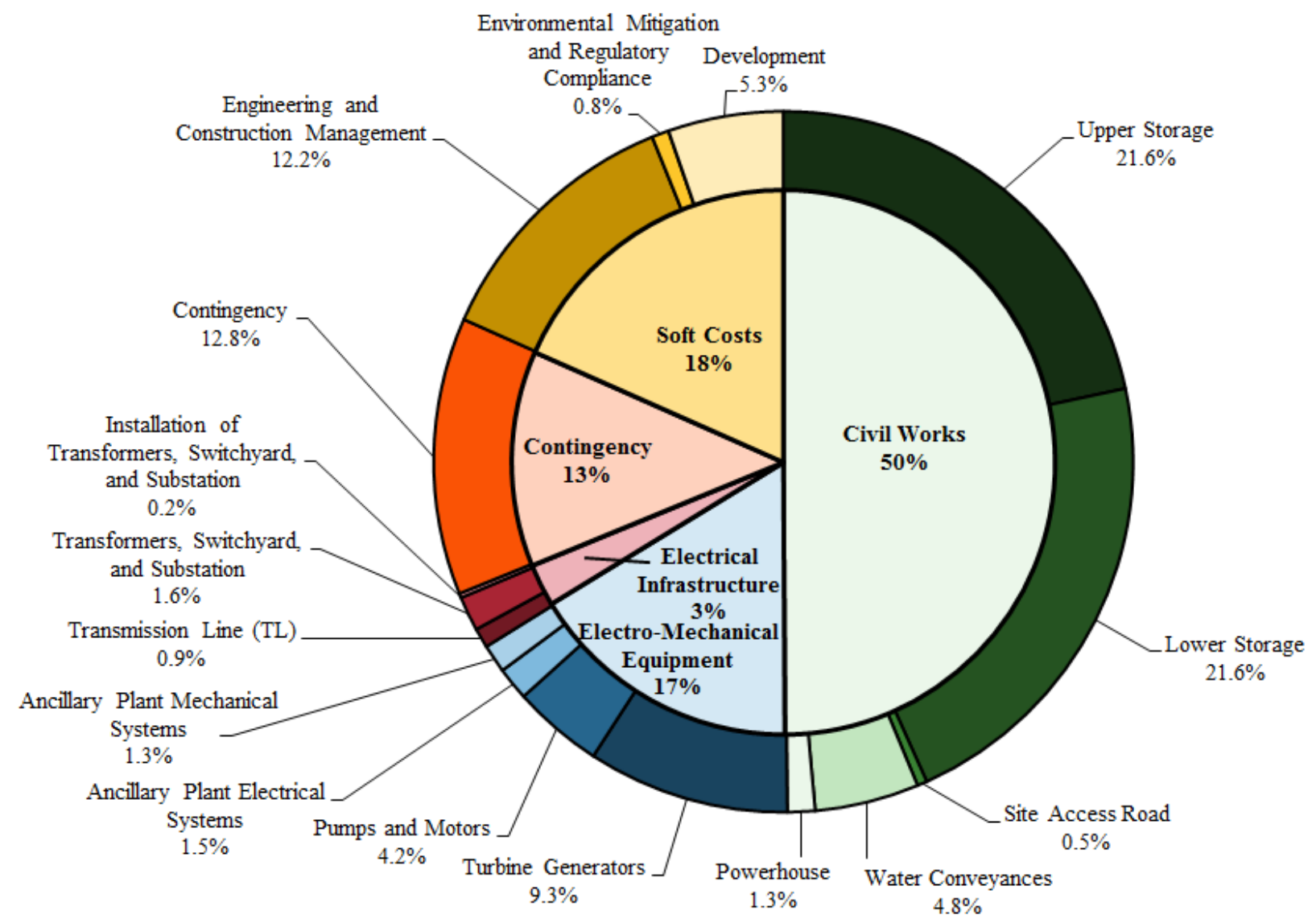

Figure 11. Approximate installed cost distribution for the m-PSH portion of a hybrid energy storage system.

Using the energy storage capacity of $5,500 \mathrm{kWh}$, the cost of $\mathrm{m}-\mathrm{PSH}$ storage is $\$ 1,129 / \mathrm{kWh}$. A cost comparison against an operational sodium-sulfur battery farm ${ }^{5}$ and several other alternative battery storage technologies (Akhil et al., 2013) shows the cost of m-PSH hybrid storage near the high end of energy storage options (Figure 12). Further cost reductions on the m-PSH system are needed to ensure the hybrid system is competitive with existing battery storage alternatives.

\footnotetext{
${ }^{5}$ http://news.nationalgeographic.com/news/2010/03/100325-presidio-texas-battery/
} 


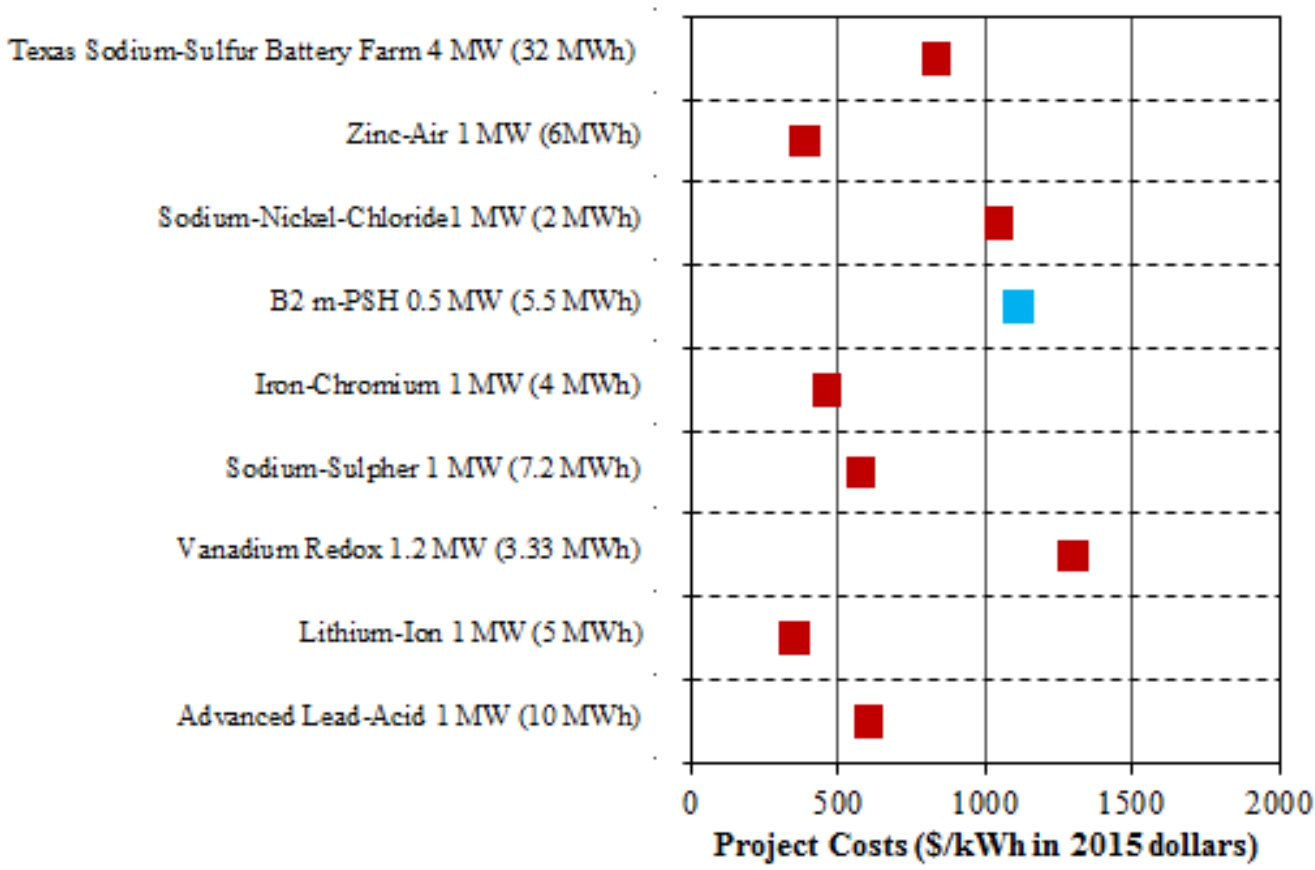

Figure 12. Approximate cost of installed storage $(\$ / \mathrm{kWh})$ for various electrical energy storage technologies.

The cost estimates are subject to several limitations which require more detailed analysis through an engineering feasibility study:

- To accommodate B2 energy needs and conceptually achieve a maximum benefit, separate pump and turbine systems were included with different capacities. Several technoeconomic challenges are not considered in detail, including bifurcation of the penstock, submergence requirements for the pump, and sizing of the penstock with respect to both pump and generation capacities and flow rates.

- The cost of civil works are subject to contingencies whose magnitude varies based on site-specific conditions - further refinement may be necessary upon site inspection.

\subsection{Total hybrid system cost}

The combined initial capital cost (ICC) of a hybrid system that enables high energy independence at B2 is estimated as $\$ 12,859,536$, nearly evenly distributed between solar and $\mathrm{m}$ $\mathrm{PSH}$ systems. Using total hybrid generating capacity of $4,090 \mathrm{~kW}$, normalized ICC is estimated at $\$ 3,144 / \mathrm{kW}$. 


\section{Economic Analysis}

The benefit-cost ratio (BCR) is used to determine the overall value of the hybrid project. A BCR greater than 1 indicates the benefits generated by the project are greater than the costs to build and operate it over the expected useful life. The BCR is calculated as the ratio of the net present value of lifecycle benefits to the net present value of lifecycle costs,

$B C R=\sum_{i=1}^{n} \frac{\text { Benefits }_{i}}{(1+r)^{i}} /\left(I C C+\sum_{i=1}^{n} \frac{\text { Costs }_{i}}{(1+r)^{i}}\right)$

where Benefits is the present value of future energy bill savings and solar revenues adjusted for inflation, Costs includes the present value of future annual operations and maintenance and replacement (O\&M\&R) costs adjusted for inflation, $r$ is the discount rate, ICC is initial capital cost, and $n$ is the life of the project. To calculate the annual benefit, annual excess solar for 2015 is estimated using the daily average solar power to grid for each month as 2,383,273 kWh. Using the high end of the SEIA 2016 Q1 estimate of utility-scale power purchase agreement pricing of $\$ 0.05 / \mathrm{kWh}$ as a best case scenario, projected annual revenue from excess solar is $\$ 119,163$. Using an annual electricity bill of $\$ 420,000$, the annual net benefit is taken as $\$ 539,163$. A full list of assumptions used to compute a baseline BCR are shown in Table 6 .

Table 6. Economic analysis assumptions

\begin{tabular}{lcc}
\hline Category & Value & Quantity \\
\hline Discount rate & $7 \%$ & - \\
\hline Inflation rate & $2 \%$ & - \\
\hline Annual avoided tariff rate escalation & $1 \%$ & - \\
\hline Annual solar O\&M (fixed) & $\$ 18 / \mathrm{MWh}$ & $\$ 65,340 /$ year \\
\hline Solar replacement cost at 25 years & $50 \%$ of ICC & $\$ 2,613,600$ \\
\hline Annual m-PSH O\&M (fixed) & $\$ 7 / \mathrm{MWh}$ & $\$ 14,372 /$ year \\
\hline m-PSH replacement cost at 25 years & $20 \%$ of ICC & $\$ 1,228,794$ \\
\hline Project lifetime & 50 years & - \\
\hline
\end{tabular}

Major assumptions in estimating economic variables include:

- Conventional pumped storage plants have a project life of well over 50 years while solar plant life is generally estimated at 25-30 years. It is assumed that half of the solar plant could be salvaged at 25 years and upgraded to last another 25 years. The m-PSH plant is assumed to require a major overhaul at 25 years.

- Annual solar O\&M is assumed based on a national market analysis in the $\mathrm{US}^{6}$.

- Annual m-PSH O\&M is an estimate based on costs for larger scale projects.

\subsection{Results and discussion}

Using these assumptions, economic analyses were conducted for several combinations of initial capital costs (Table 7). For the baseline total system cost, a BCR of 0.72 indicates lifetime project costs outweigh lifetime benefits. Incremental cost reductions of each sub-system show

\footnotetext{
${ }^{6} \mathrm{http}: / /$ www.nrel.gov/analysis/tech_lcoe_re_cost_est.html
} 
that the BCR rises above 1.0 at $73 \%$ of the projected solar ICC and $65 \%$ of the projected m-PSH ICC, assuming the same benefit is maintained.

Table 7. Economic indicators for a hybrid energy storage and generation system with projected theoretical cost reductions.

\begin{tabular}{ccccc}
\hline Solar ICC $(\mathbf{\$} / \mathbf{k W})$ & \% of baseline & m-PSH ICC $(\mathbf{\$} / \mathbf{k W})$ & \% of baseline & BCR \\
\hline 1,800 & 100 & 13,666 & 100 & 0.72 \\
\hline 1,620 & 90 & 13,666 & 100 & 0.76 \\
\hline 1,440 & 80 & 13,666 & 100 & 0.80 \\
\hline 1,800 & 100 & 12,299 & 90 & 0.75 \\
\hline 1,800 & 100 & 10,933 & 80 & 0.79 \\
\hline 1,620 & 90 & 12,299 & 90 & 0.80 \\
\hline 1,440 & 80 & 10,933 & 80 & 0.88 \\
\hline 1,314 & 73 & 8,883 & 65 & 1.00 \\
\hline
\end{tabular}

These results indicate significant reductions in the projected costs from Section 4 are necessary for a hybrid project that enables high energy independence to achieve economic feasibility. The largest cost drivers for the m-PSH system are the water storage tanks. It is possible that improved economic metrics could be achieved with small, excavated basins rather than with large water storage tanks. In this case, the site would require more extensive site preparation, including excavation and the application of geomembranes to prevent seepage and leakage. If cost reductions down to $50 \%$ of current tank storage costs were achieved, the project ICC would be reduced to $\$ 9,355 / \mathrm{kW}$, a $30 \%$ reduction compared to the baseline scenario outlined above. On the solar side of the hybrid system, the PV modules and the soft costs of development are the largest cost drivers. Commercial and utility-scale solar installed prices have been cut in half since 2010 and continue to show incremental decreases on a quarterly basis (Chung et al., 2015). It is plausible that, through cost reductions achieved via innovative m-PSH design coupled with the rapid cost reductions presently occurring in the solar industry, baseline ICC scenario may be reduced towards the point of economic feasibility.

Additional sensitivity analyses are carried out to assess the effect of uncertainty in baseline assumptions on the economic feasibility of the project (Figure 13). The tested parameters with the strongest influence on the BCR include the annual escalation rate of the avoided tariff, and the ICC of the project. The annual tariff escalation represents a yearly increase in the electricity rate charged by the utility. On a regional scale, commercial electricity costs are projected to increase $0.25 \%$ per year in the western $\mathrm{US}^{7}$. On a local scale, future uncertainty in electricity rates may be greater due to the reliance on hydropower in a drought-prone region. If hydropower becomes increasingly expensive or unavailable, electricity rates may increase significantly and abruptly. In 2007, for example, the local utility providing service to B2 added a $\$ 0.0218 / \mathrm{kWh}$ charge to each $\mathrm{kWh}$ used by customers. This charge reflected an overnight increase of greater than $40 \%$ in the hourly electricity rate - with an annual escalation rate of $1 \%$, it would take nearly 24 years for the electricity rate to achieve the same magnitude of increase. The impact of future rate increases should be studied in more detail to inform the overall economic feasibility of the hybrid project. Strategies to achieve a strong reduction in ICC, as discussed above, should also be analyzed in greater detail.

\footnotetext{
${ }^{7}$ http://www.nrel.gov/analysis/lcoe/includes/pdfs/us_map_cost_escalations_title.pdf
} 


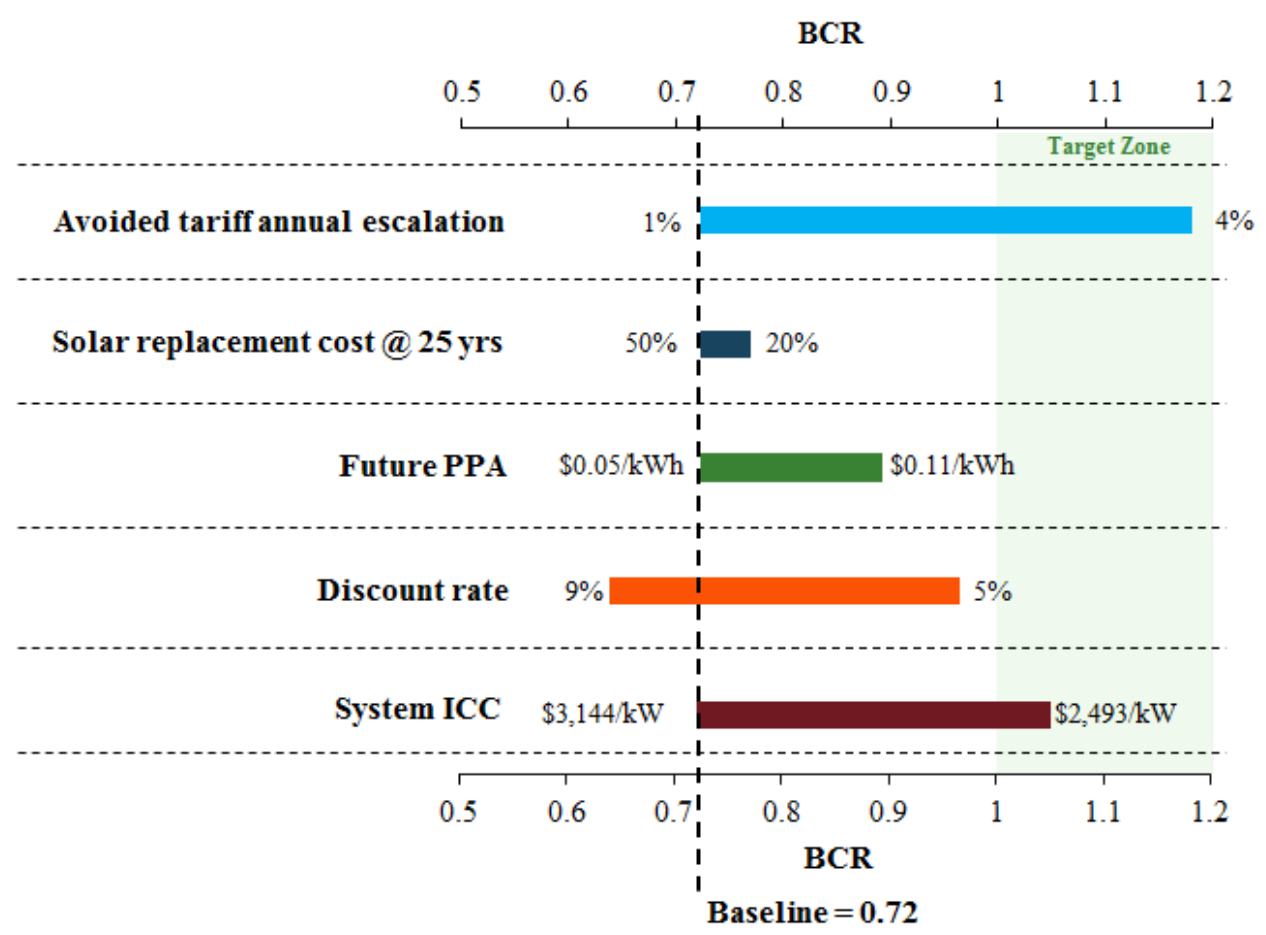

Figure 13. Financial sensitivity to various economic parameters.

\subsection{Modeling limitations}

This economic analysis provides high level insight into the cost and benefit dynamics of a hybrid solar and m-PSH energy project. There are several model limitations that must be considered in any future analysis of the economic feasibility of this project:

- The analysis does not explicitly include the effect of taxes or any tax benefit in the form of an investment tax credit (ITC) for solar or storage. Inclusion of the current solar ITC of $30 \%$ and/or the proposed $30 \%$ energy storage ITC would shift the project benefits in a positive direction.

- The analysis only accounts for financing interest rates, financing terms, ownership structure, desired investor returns, and taxes through a sensitivity analysis on the discount rate. A more detailed cash flow analysis will give a better sense of the timing and magnitude of annual cash flows and how they affect project feasibility.

- The annual benefit is determined based on an assumption that storage and solar can cover all energy needs at B2. This is an idealization that does not account for instantaneous fluctuations in irradiance and energy demand. Realistically, a small amount of energy would still need to be purchased from the utility unless storage reservoir volumes were increased substantially. A more detailed instantaneous energy and irradiance analysis will provide a clearer picture of how much energy would be purchased from the grid.

- The model assumes the costs of interconnecting the solar and m-PSH resources are included in the m-PSH project contingency. As a first-of-its-kind project, there may be unforeseen expense and development challenges that would add additional electrical infrastructure costs. 


\section{Conclusions and Recommendations}

A preliminary assessment is carried out to determine the economic feasibility of a hybrid solar driven m-PSH system designed to enable high energy independence at B2. Major findings, along with future research recommendations, are as follows:

- It is technically feasible to construct a hybrid solar driven modular pumped storage facility using existing technologies. The major impediment to project realization is cost.

- The benefits of using tank storage, including the reduction in evaporative losses and modular-type development and capacity expansion, are offset by high costs. Water storage comprises nearly $50 \%$ of the total cost of the m-PSH system.

- Future research should focus on using alternatives to storage tanks. A simple excavated basin used as a storage pond could lower storage costs, though unique cost drivers include the complexity of the surrounding terrain, the composition of the subsurface geology, the need for a cover to reduce evaporation, and compensation water to replace evaporative losses.

- Seasonal changes in the load profile of solar have a strong influence on m-PSH pump power, the number of hours when pumping is feasible, and the storage capacity of the system. For example, a pump can be sized to use all excess solar capacity during a day in December to fill an upper reservoir. This same size pump will fill the upper reservoir quicker in July when excess solar is available at a higher power output earlier in the day.

- The $\mathrm{kW}$ available to run a pump and the $\mathrm{kW}$ produced during turbine generation are not identical. Solar power sent to the pump gradually ramps up and down, peaking at mid-day, while off-peak generation remains relatively constant to meet B2 power demand.

- If there is potential to modify the operation of the eutectic salts in the chillers to take up an additional portion of excess energy during the day, the m-PSH system size and cost may be reduced. Future efforts can integrate the chiller operational constraints, in addition to any electricity system flexibility at B2 not considered in this report, into the hybrid storage design to identify where additional benefits and tradeoffs can be realized.

- The costs of solar PV installations are consistently falling, while the cost of m-PSH carries more uncertainty. Further cost reductions and innovations in design of m-PSH are necessary for a hybrid project to achieve economic feasibility.

- A 3-1 solar power to storage power ratio is common for cost-competitive demand management systems (Kraemer, 2016). Smaller solar and m-PSH capacities should be explored in combination with potential future demand charge and tariff increases to quantify the economic feasibility of a hybrid system used for demand charge management.

- The annual energy saved by taking B2 off the grid, approximately 4.3 million $\mathrm{kWh}$, could be used to power an additional 300 homes $^{8}$. The monetary and non-monetary value of this energy to both homeowners and the utility could be significant.

- An attempt should be made to quantify the academic and social benefit/value of a novel hybrid renewable energy generation and storage system. This value may be independent of project size and could add significantly to the value proposition of the system. If this value is incorporated into the economic assessment, it would improve the overall feasibility of the project.

\footnotetext{
${ }^{8}$ Assuming annual average energy consumption of $14,300 \mathrm{kWh}$ per home (https://www.eia.gov/consumption/residential/reports/2009/state_briefs/pdf/az.pdf)
} 


\section{References}

Akhil, A., Huff, G., Currier, A., Kaun, B., Rastler, D., Chen, S., Cotter, A., Bradshaw, D., Gauntlett, W. (2013). DOE/EPRI 2013 Electricity Storage Handbook in Collaboration with NRECA. http://doi.org/SAND2013-5131

Chung, D., Davidson, C., Fu, R., Ardani, K., \& Margolis, R. (2015). U.S . Photovoltaic Prices and Cost Breakdowns : Q1 2015 Benchmarks for Residential, Commercial, and Utility-Scale Systems. National Renewable Energy Laboratory.

Kraemer, S. (2016). When is Energy Storage Eligible for the 30 Percent ITC? Renewable Energy World, February 17, 2016. < http://www.renewableenergyworld.com/articles/2016/02/when-is-energystorage-eligible-for-the-30-percent-itc.html>

MWH. (2009). Technical Analysis of Pumped Storage and Integration with Wind Power in the Pacific Northwest.

O'Connor, P., Zhang, K., Deneale, S. T., Chalise, D. R., \& Centurion, E. (2015). Hydropower Baseline Cost Modeling. Oak Ridge, TN: ORNL/TM-2015/14.

Witt, A., Hadjerioua, B., Uria-Martinez, R., \& Bishop Jr., N. A. (2015). Evaluation of the Feasibility and Viability of Modular Pumped Storage Hydro (m-PSH) in the United States. Oak Ridge, TN: ORNL/TM-2015/559.

Witt, A., Chalise, D., Hadjerioua, B., Bishop, N., Manwaring, M. (2016). Development and Implications of a Predictive Cost Methodology for Modular Pumped Storage Hydropower (m-PSH) Projects in the United States. Oak Ridge, TN: ORNL/TM-2016/590. 